\title{
大型宇宙構造物の同定実験
}

\author{
足立修一*·重政隆**.山口功***
}

\section{Identification Experiments for a Large Space Structure}

Shuichi Adachi*, Takashi Shigemasa**, Isao Yamaguchi*** and Takashi KidA***

This paper considers the modal parameter identification problem for an LSS (Large Space Structure) from measured input-output data. The selection of setting parameters for identification, such as the sampling rate and identification model order, has great influence on the identification accuracy. This paper proposes a new identification method which uses decimated input-output data. The decimation consists of two parts, first the input-output data are filtered by low-pass filters, and then resampled by the lower sampling rate. The elastic modes can be identified accurately by proper choice of the cut-off frequency of the filter. In the proposed identification method, the model order is determined by the frequency domain criterion, that is, the flatness of the identification residual sequence. The effectiveness of the proposed identification method is shown by identification experiments which were carried out by using a groundbased test model.

Key Words : identification, LSS (Large Space Structure), modal parameter, decimation, filter

\section{1.はじめに}

近年, 人工衛星の大型化 - 軽量化に伴い, 柔軟性に 起因する振動モードの姿勢制御系への干渉に代表され る大型宇宙構造物 (LSS) の同定・制御問題が広く関心 を集めている1).

†第18 回制御理論シンポジウムで発表 (1989・5)

* (株) 東芝総合研究所 (現在宇都宮大学工学部 宇都宮 市石井町 2753)

** (株) 東芝総合研究所 川崎市川崎区浮島町 4-1

*** 航空宇宙技術研究所 調布市深大寺東町 7-44-1

* R \& D Center, Toshiba Corporation (Presently, Faculty of Engineering, Utsunomiya University, Utsunomiya)

** R \& D Center, Toshiba Corp., Kawasaki

*** National Aerospace Lab., Chofu (Received March 6, 1990)

(Revised June 22, 1990)
一般に衛星の動特性は，地上試験や FEM モデリン グに代表される計算機シミュレーションによって同定 され，その同定結果に基づいて姿勢制御系を設計して いる ${ }^{2)}$. しかし衛星の大型化に伴い，重力や大気の影 響，支持の問題など宇宙空間と地上との環境の違いが 無視できなくなってきており，また地上実験を実施す るととも困難になってきている，したがって，宇宙空 間の軌道上において衛星のシステム同定を行い，その 結果に基づいて姿勢制御系の制御定数をチューニング する必要性が今後増してくることが予想される. また，現状では姿勢制御系のほとんどが PID 制御を ベースにした古典的な制御系設計手法で設計されてい るが，今後通信衛星のアンテナ指向制御に代表される 高精度な制御系の開発に向けて, いわゆる現代制御理 論の適用検討も重要な課題である. このような要請を 満たすためには，軌道上で振動モードを高精度に同定 する技術が必要不可欠となる.

本論文では, 同定対象の入出力データにデシメーシ ヨン操作を施した後に, 最小 2 乗法を適用する同定法 を取り上げ，LSS の同定法として有効であることを 実験データを通して明らかにする. デシメーションと は，ある信号に対して低域通過（あるいは帯域通過） フィルタを作用させ, その出力信号をむとのサンプリ ング周期より荒いサンプリング周期で間引く（デシメ ートする）信号処理のととであり，最近システム同定 にも適用されはじめ, その有効性が示されてきてい る3，4). このとき, 著者らは複数個のフィルタを用い て対象の周波数特性の帯域分割を図ることにより，広 帯域にわたって高精度な同定が行える方法を提案した が32,5), 着目したい周波数帯域があらかじめわかって いる場合には，そとを通過帯域とするフィルタを利用 したほうが，より高精度な同定が期待できる. 本論文 では, 補助的な出力信号（たとえば, 衛星搭載の加速 度計の信号）の周波数特性を利用するととにより，デ シメーションで用いるフィルタを決定する方法を提案 する. また，同定残差のパワースペクトルの平坦さと 
いう評価を用いて，同定モデルの次数を決定する.

本論文の目的は，提案する同定法の有效性を実験に よって検証することである。，そのために，中心剛体に 太陽電池パドルが付着している衛星を模擬した地上実 験装置に対して同定実験を行い，収集した入出力デー 夕に対して本同定法を適用し, 同定モデル次数, デシ メーションの次数と振動パラメータの同定精度との関 係を調べる，そして，同定されたパラメータを用いて 現代制御理論により姿勢制御系を設計し，制御実験を， 行い, 同定結果の妥当性を確かめる.

\section{2. 問題の説明}

次式の 1 入出力連続時間システムを考える.

$$
y=G(s) u
$$

ただし，uは入力 (トルク)，yは出力 (姿勢角) であ る. 本論文では LSS の伝達関数を次式のように仮定 する.

$$
G(s)=\frac{1}{I s^{2}}+\sum_{i=1}^{\infty} \frac{\phi_{i}^{2}}{s^{2}+2 \zeta_{i} \omega_{i} s+\omega_{i}^{2}}
$$

ただし，I は衛星本体の慣性モーメント， $\left\{\omega_{i}\right\}$ は振 動モードの共振周波数, $\left\{\zeta_{i}\right\}$ は減衰比, $\left\{\phi_{i}\right\}$ はトル クアドミタンスである. 本論文では, センサとアク チュエータが同位置に配置されている(てれを collocation という）場合を想定しているため，(2)式は 最小位相系になっている. LSS は (2)式で示したよ うに無限個の振動モードを含むが，一般にその内のい くつかの低次のモードに基づくモデルに対して制御系 設計を行う，したがって，本論文では剛体モードと低 次モードのパラメータを入出力データに基づいて同定 する問題を考察する.

(1) 式の連続時間システムをあるサンプリング周期 ( $\Delta T$ とする) により離散化すると，つぎの離散時間 システムが得られる.

$$
A\left(z^{-1}\right) y(k)=B\left(z^{-1}\right) u(k)+e(k)
$$

ただし，

$$
\begin{aligned}
& A\left(z^{-1}\right)=1+a_{1} z^{-1}+\cdots+a_{n} z^{-n} \\
& B\left(z^{-1}\right)=b_{1} z^{-1}+b_{2} z^{-2}+\cdots+b_{n} z^{-n}
\end{aligned}
$$

であり， $e(k)$ は雑音を表わす. 実際の人工衛星におい ては, 姿勢角センサのセンサノイズは小さく, 白色性 とみなせることが多いため，(3)式のモデルを仮定し た。

(3)式はつぎのように書き直せる.

$$
y(k)=\theta^{T} \boldsymbol{x}(k)+e(k)
$$

ただし、

$$
\boldsymbol{\theta}=\left[a_{1}, \cdots, a_{n}, b_{1}, \cdots, b_{n}\right]^{T}
$$

$$
\begin{aligned}
x(k)= & {[-y(k-1), \cdots,-y(k-n),} \\
& u(k-1), \cdots, u(k-n)]^{T}
\end{aligned}
$$

ここで, $\theta$ が同定されるパラメータベクトルである. 本論文では, 最小 2 乗法を用いてパラメータベクトル $\theta$ の推定值 $\hat{\theta}$ を求めることにする. そして, 得られた パラメータ推定值から，付録に示した方法を用いて主 要振動モードのモードパラメータを計算する.

\section{3. デシメーションを用いたパラメータ同定}

従来から LSS のような振動系は, 同定しにくいシ ステムであるとされている. 特に，(2)式で記述され るような剛体モードを含む振動系は, ゲイン特性にお いて、 $-40(\mathrm{~dB} /$ decade) が支配的亡なるため, 低域之 高域に扔いてゲインのレベルの差が大きく, 数值的に 悪条件となるからである. とのとき, 着目する振動モ ードを励起するようなサンプリング周期を用いて入力 信号を印加し，それに対して最小 2 乗法を適用する方 法の有効性が指摘されている6). この考え方は, 古典 的な周波数応答法の延長上に位置づけるととができる が, 多数の異なる周波数の振動モードを同定する場 合，何種類むの異なるサンプリング周期の同定入力を 用意する必要があり，実用的ではない。

実際に衛星の同定では，サンプリング周期を任意に 選択することはできず，与えられた同定条件下で精度 よく同定できるアルゴリズムが必要となる，そこでデ シメーションの利用を考える゙〉 -5). まず, 高周波領域 における情報の損失を防ぐために, 同定対象の入出力 データを可能な限り小さなサンプリング周期でサンプ リングする，LSS の場合，高周波数帯域における振動 モードに起因するスピルオーバ対策が制御系設計にお いて重要な課題になるため, 高周波数帯域の同定屯重 要であるからである.つぎに，それらの入出力データ を低域通過フィルタに入力し, その出力を $d \Delta T$ でサ ンプリングし直す．こてで， $d$ をデシメーションの次 数之呼ぶ. 乙の操作は $(d-1)$ 個ごとに間引いてサン プリングするととと等価である.また，低域通過フィ ルタのカットオフ周波数は，d対応して選ばれる. そして，デシメーションされた入出力データに対して 最小 2 乗法を適用し，パラメータ同定を行う．乙のよ うに，フィルタリングを適切に行い，低域に焦点を合 せるととにより，細かいサンプリング周期では同定し にくかった低域の振動モードを精度よく同定すること が可能になる．またデシメーションを用いると，サン プリング周期をソフトゥェアで簡単に変更するととが でき，一つの実験データから異なる同定条件を設定す るととができる。 
つぎにフィルタのカットオフ周波数（等価的にデシ メーションの次数）の選定法について説明する. 著者 らは，デシメーションを複数個並列に利用することに より，同定対象の周波数特性を帯域分割し，それぞれ に対して最小 2 乗法を適用する同定法を提案した ${ }^{32,5)}$. そのときデシメーションの次数は, あらかじめ $d=1$, $2,4,8, \cdots$ と与える立場をとっていたが，衛星を同定 対象とした場合には，地上試験などによる事前情報， あるいは本同定実験ではパネル先端に取り付けた加速 度計の出力の周波数特性を参照して着目する振動モー ドに焦点のあったデシメーションの次数を決定するて とができる。

最後に, 同定モデルの次数決定手順について説明す る. まず，複数個の次数の異なる同定モデルを準備 し，それぞれに入出力データを入力し，最小 2 乗法を 用いて伝達関数の係数パラメータを推定する.つぎ に，それぞれの推定值に基づいて残差系列を計算し， それに対してたとえばFFT を適用して，残差系列の パワースペクトルを求める. このパワースペクトル が平坦になる最小のモデル次数を同定モデルの次数と し，そのときの推定值を用いて同定対象の周波数特性 を計算する.

\section{4. 同定実験}

\section{1 大型衛星の地上実験装置7)}

大型衛星の姿勢運動を Fig. 1 亿示す 1 軸エアテー ブル装置で模擬した．大型太陽電池パドルに相当する 柔軟構造模型は 2 枚の CFRP (炭素繊維複合材) パネ ルをヒンジで結合したものを使用し，てれが中心剛体 のテーブルに取り付けられている。テーブル回転角は 非接触磁気回転計（分解能 $0.005(\mathrm{deg})$ ) で計測し, ブラシレス DC トルクモータ（最大 $0.4(\mathrm{Nm})$ ) を アクチュエータとする collocate した入出力構成であ る. 以下の同定実験では，入力信号はすべて $\mathrm{M}$ 系列 信号とした。 また補助出力測定用として, パネル先端 に加速度計 (ACC) を取り付けた.

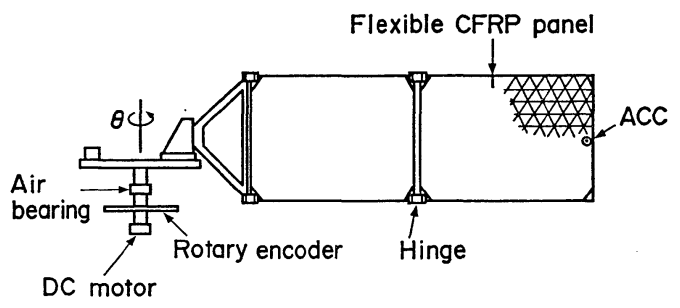

Fig. 1 Flexible apparatus

\section{2 同定実験結果}

(a) 同定モデル次数の決定

まず， $\Delta T=50$ (ms) とした場合の実験結果 (Fig. 2 に実験より得られた入出力データを示した）を用い て，同定モデル次数と振動モードの同定結果の関係に ついて調べる. ととで, データ長は $14.5(\mathrm{~s})$, データ 数は 290 (個) である. 乙のとき, 同定モデル次数 $(n)$ を 4,10,20 之順次増加させてゆき，それぞれに対し て最小 2 乗同定を行い，推定された周波数応答と同定 残差のパワースペクトルを Fig. 3 に示した.

四中に点線で示したゲイン・位相特性は, 有限要素 法をべースにした構造解析 ${ }^{21}$ 上り得られた同定結果で ある. この方法は, パネル単体で構造解析を行い, つ ぎ衛星本体であるエアテーブルの特性と合成すると とによって全体のモードパラメータを求める手順を踏 んでいる，乙のとき減衰比は同定できないため，適当 な值を最後につけ加えている。すすなわち, 構造解析は パネルをエアテーブルにとりつけた状態で行っていな いため，以下で示す本同定結果とは多少異なった值を とっている. 一方, 本同定法は中心剛体にパネルがと りつけられているという実際の衛星の形状に対して行 えるため，宇宙空間上での軌道上同定実験を想定した 場合，非常に有効であると思われる.

Fig. 3(a) より明らかなように，モデル次数が小さ いときは 1 次振動モードが同定できていない，乙の場 合，1(Hz) あたりに残差スペクトルの鋭いピークが 検出され，残差スペクトルは平坦になっていない。モ デル次数を増加させていくと, Fig. 3(b)，（c）に示
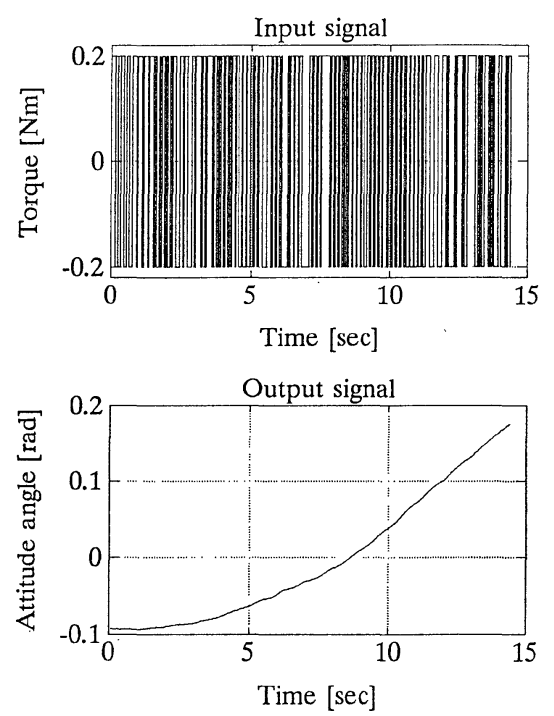

Fig. 2 Input-output data obtained by identification experiment $(\Delta T=50(\mathrm{~ms}))$ 

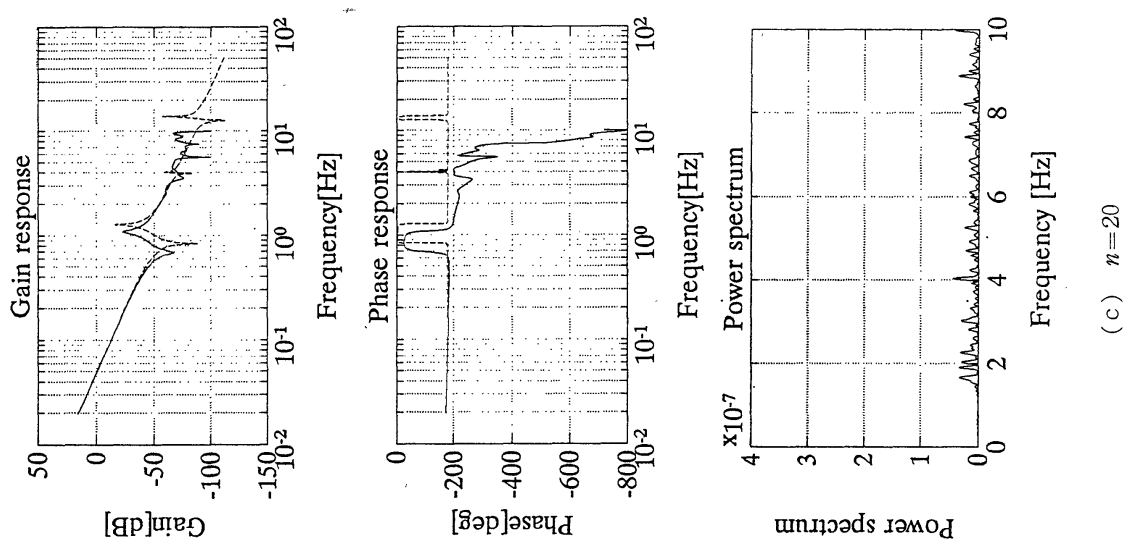

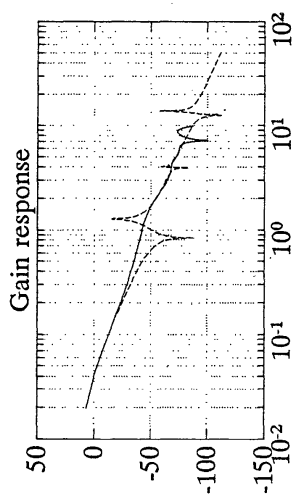

[gp]uाe?

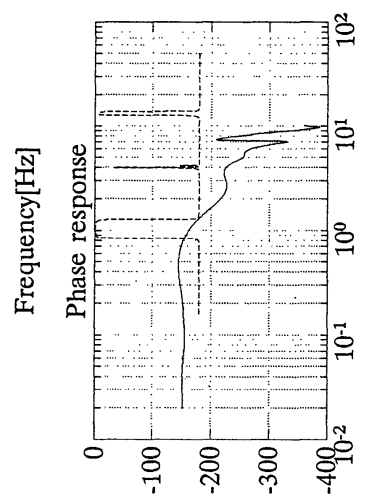

[ริวp]əseчd
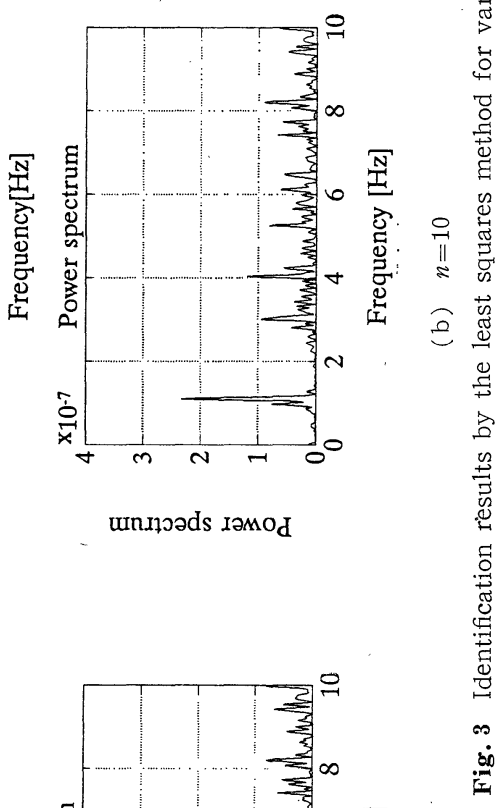

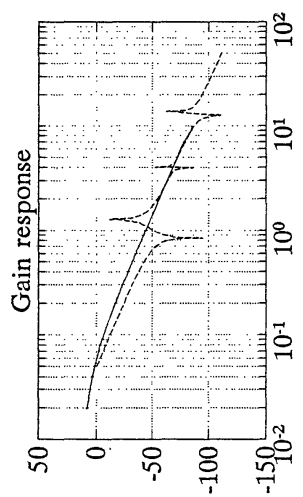

[qp]urẹ

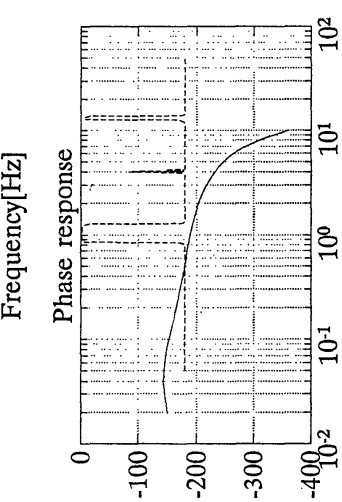

[в̈әр]әsечน

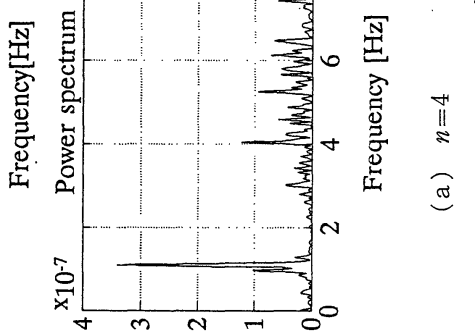

unnџวds זamod 
したように残差スペクトルがしだいに平坦になってい き， $n=20$ としたとき 1 次振動モードが精度よく同定 できているととがわかる.

てのように, 同定残差のパワースペクトルの平坦さ をみるととにより，振動モードが同定できているかど うかを判定するととができ，乙の場合には $n=20$ と いう高次のモデルを用いないと 1 次振動モードが同定 できないととが明らかになった。

たとえば，剛体モードと 1 次振動モードのみを同定 するのであれば， 4 次のモデルを用意すればよいよう に思わ机るが，Fig. 3 より明らかなように， $n=4$ の 場合には 1 次振動モードすら同定できていない。最小 2 乗法は，基本的に時間領域における誤差の 2 乗和を 最小にするてとを目的としているため，次数の小さな モデルではゲインの小さな振動モードは雑音などと区 別できずに無視されてしまっている．乙のように実デ 一タの出力信号の中には入力信号によって駆動された 対象の可制御・可観測な成分ばかりではなく，雑音や 外乱などの非可制御な成分も含まれている，したがっ て，同定モデル次数は非可制御な成分を考慮してやや 高めに設定しておいたほうがよいととが経験的に知ら れていたが8)，従来は試行錯誤に頼って決定すること が多かった。 そ机に対して，こてで用いた同定残差の スペクトルの平坦さに着目した次数決定法は定性的な 方法ではあるが実際的なあのであり，実データに対し ても有効性が確認できた。

(b) デシメーション次数の決定

前節ではモデル次数を高めに選定すれば，振動モー
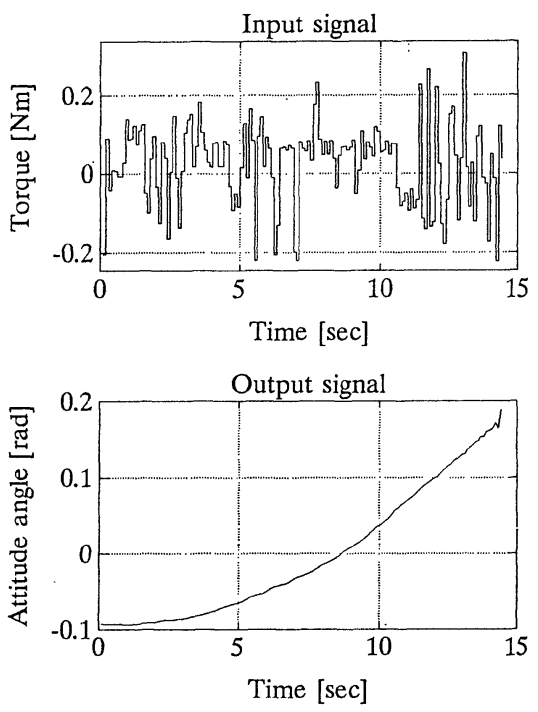

Fig. 4 Decimated input-output data $(d=2)$
ドを同定できる可能性があるととを示したが，以下で はデシメーションを有効に利用すれば，より低次のモ デルによっても同等以上の同定が行えることを示す.

まず，Fig. 2 亿示した入出力データ $(\Delta T=50(\mathrm{~ms}))$ に対して $d=2$ のデシメーションを適用した結果を

Fig. 4 亿示す. $\Delta T=100(\mathrm{~ms})$ 飞対応するての入出力 データに対して， $n=10$ として最小 2 乗同定を行った 結果を Fig. 5 に示した. Fig. 3(b) と比較すると, デシメーションを用いるととにより, 同じモデル次数 で 1 次振動モードが高精度に同定できるととがわか る.

さて， $\Delta T=50(\mathrm{~ms})$ ではナイキスト周波数が 10 $(\mathrm{Hz})$ であるため, $10(\mathrm{~Hz})$ より少し高いところに存 在する 3 次振動モードを同定することができなかっ た．そこで， $\Delta T=20(\mathrm{~ms})$ としたときの実験データ (Fig. 6) を用いることにする. このとき, データ長 は Fig. 2 の場合とほぼ同じであるが，サンプリング 周期が異なるためデータ数は 750 個である. Fig. 6の 入出力データに対して, $n=10$ として最小 2 乗同定を 行った結果を Fig. 7 に示した. 図より $10(\mathrm{~Hz})$ あた りに存在する 3 次振動モードは, 精度は悪いが同定で きた. しかし，1，2次振動モードはまったく同定で きていない，同定問題を(3)式のように定式化する 之，周波数領域において高域に重みがかかった評価関 数となるため, 低域の振動モードは同定が難しくなる ためである ${ }^{4}$.

そこで，デシメーションを利用した同定法を適用す る.まず，デシメーションの次数選定は，Fig. 8 に
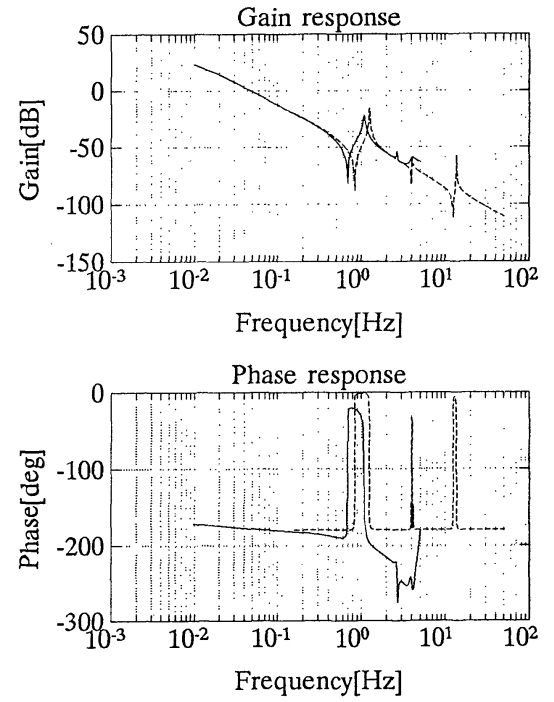

Fig. 5 Identified frequency response by using decimated data 

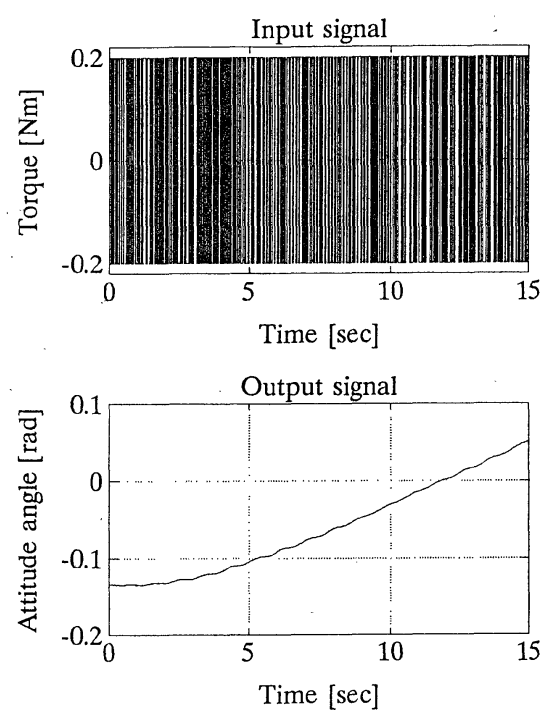

Fig. 6 Input-output data obtained by identification experiment $(\Delta T=20(\mathrm{~ms}))$
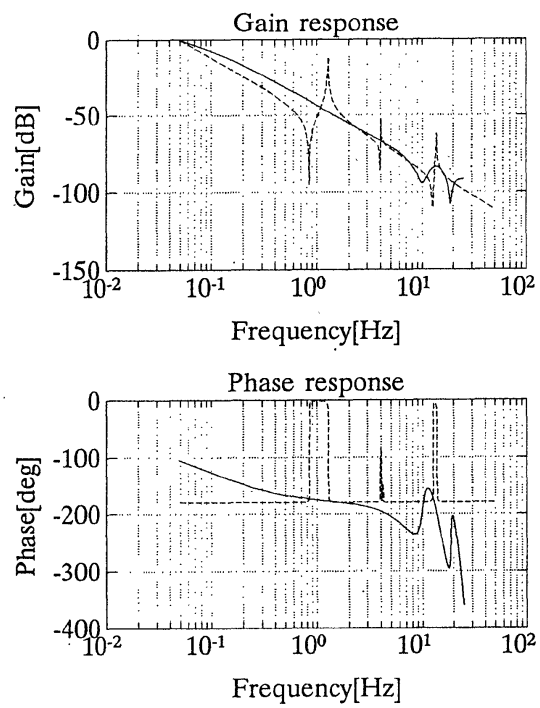

Fig. 7 Identification results by the least squares method $(n=10)$

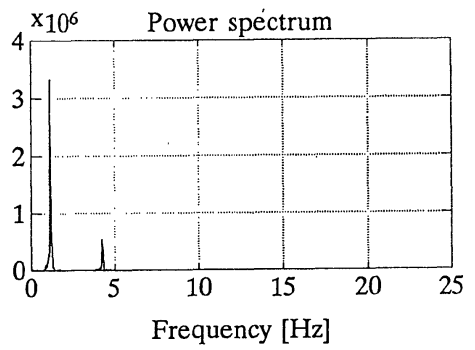

Fig. 8 Power spectrum of acceleration signal
示すパネル先端に取り付けた加速度計より得られた信 号のパワースペクトルを利用して行った. Fig. 8 よ り， 1,4( $\mathrm{Hz})$ 近辺に振動モードが存在することがわか る. そこで, カットオフ周波数 $f_{c}=12.5(\mathrm{~Hz})$ ，すな わち $d=4$ とした: そのときの, デシメーションされ た入出力信号を Fig. 9 に示し, その入出力データ を用いた最小 2 乗推定を行い; 求まった周波数応答を Fig. 10 に示した $(n=10)$. また, 同定された 1 次振 動モードのパラメータを Table 1 に示した. このよ
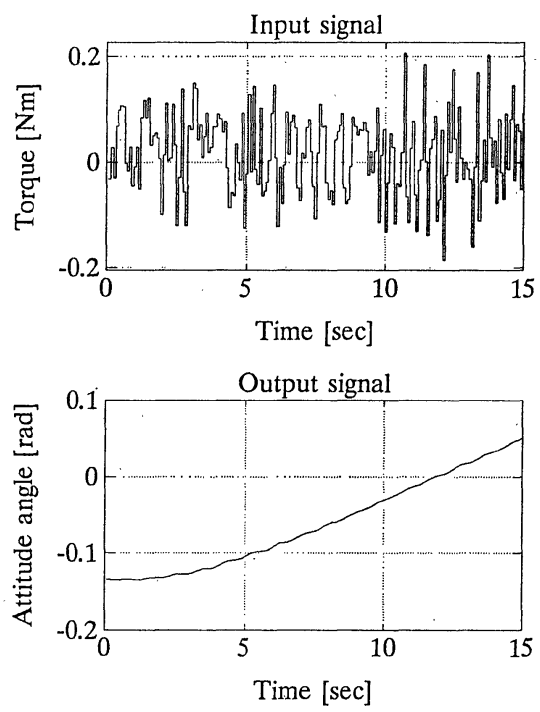

Fig. 9 Decimated input-output data $(d=4)$
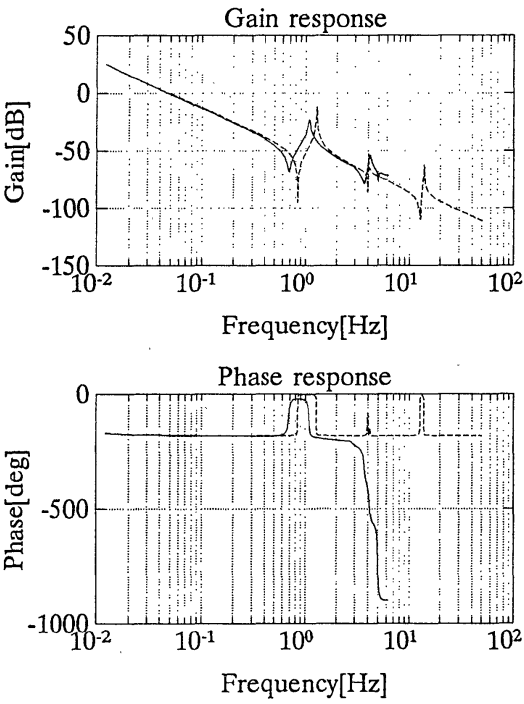

Fig. 10 Identified frequency response by using decimated data 
Table 1 Identified modal parameters

\begin{tabular}{c|c|c}
\hline \hline Parameter & Nominal value & Identified value \\
\hline $\begin{array}{c}\text { Natural frequency: } \\
f_{1}(\mathrm{~Hz})\end{array}$ & 1.262 & 1.082 \\
$\begin{array}{c}\text { Damping ratio: } \\
\zeta_{1}(-)\end{array}$ & 0.0020 & 0.0155 \\
$\begin{array}{c}\text { Torque admittance: } \\
\phi_{1}^{2}\left(1 / \mathrm{kg} \cdot \mathrm{m}^{2}\right)\end{array}$ & 0.1218 & 0.1446 \\
\hline $\begin{array}{c}\text { Inertia moment: } \\
I\left(\mathrm{~kg} \cdot \mathrm{m}^{2}\right)\end{array}$ & 10.47 & 10.86 \\
\hline
\end{tabular}

うに, デシメーションを適切に行うことにより, 振動 パラメータを同定するととが可能になった．ととで, 公称值として前述した構造解析の結果を示した.

\section{3 同定結果に基づいた制御実験}

ここでは，制御モードを(剛体)+(1次振動モード) とし，2次振動モード以降を残余モードとする．よっ て制御対象は, 次式のように状態空間表現できる.

$$
\begin{aligned}
& \dot{\boldsymbol{x}}(t)=\boldsymbol{A} \boldsymbol{x}(t)+\boldsymbol{b} u(t) \\
& y(t)=\boldsymbol{c}^{T} \boldsymbol{x}(t)
\end{aligned}
$$

ただし

$$
\boldsymbol{A}=\left[\begin{array}{cccc}
0 & 1 & 0 & 0 \\
0 & 0 & 0 & 0 \\
0 & 0 & 0 & 1 \\
0 & 0 & -\omega_{1}^{2} & -2 \zeta_{1} \omega_{1}
\end{array}\right], \quad \boldsymbol{b}=\left[\begin{array}{c}
0 \\
1 \\
0 \\
1
\end{array}\right], \boldsymbol{c}=\left[\begin{array}{c}
1 / I \\
0 \\
\phi_{1}^{2} \\
0
\end{array}\right]
$$

パラメータは Table 1 に示した同定值を用いた.

このシステムに対してサーボ系を設計するため，つ ぎの拡大系を考える.

$$
\begin{aligned}
& \frac{d}{d t}\left[\begin{array}{l}
\dot{\boldsymbol{x}} \\
e
\end{array}\right]=\left[\begin{array}{ll}
\boldsymbol{A} & \boldsymbol{O} \\
\boldsymbol{c}^{T} & 0
\end{array}\right]\left[\begin{array}{l}
\dot{\boldsymbol{x}} \\
e
\end{array}\right]+\left[\begin{array}{l}
\boldsymbol{b} \\
0
\end{array}\right] \dot{u} \\
& e=\left[\begin{array}{ll}
\boldsymbol{O}^{T} & 1
\end{array}\right]\left[\begin{array}{l}
\dot{\boldsymbol{x}} \\
e
\end{array}\right]
\end{aligned}
$$

ただし， $e=y-r$ は偏差であり， $r$ は目標值である. よって, 拡大系 $(7)$ ，（8)式を安定化する制御

$$
\dot{u}=-\left[\begin{array}{ll}
\boldsymbol{f}^{T} & K_{I}
\end{array}\right]\left[\begin{array}{l}
\dot{\boldsymbol{x}} \\
\boldsymbol{e}
\end{array}\right]
$$

すなわち

$$
u(t)=-\boldsymbol{f}^{T} \boldsymbol{x}+K_{I} \int_{0}^{t}\{r(\tau)-y(\tau)\} d \tau
$$

を求めることが問題となる，本論文では，乙の制御則 のフィードバックゲイン $\boldsymbol{f}=\left[f_{1}, f_{2}, f_{3}, f_{4}\right]^{T}, K_{I}$ は 折り返し法"9)を用いて設計した．折り返し法を用いる と, $s$ 平面上の虚軸に近い減衰比の悪い主要極を安定 な領域へ配置する制御系が構成できるため, 振動系に 対して非常に有効であるととが期待できる，また，状 態 $\boldsymbol{x}$ は測定するととができないので，実験では同一次 元オブザーバを用いて状態推定を行った.

行った制御実験の内容は，つぎのとおりである。ま
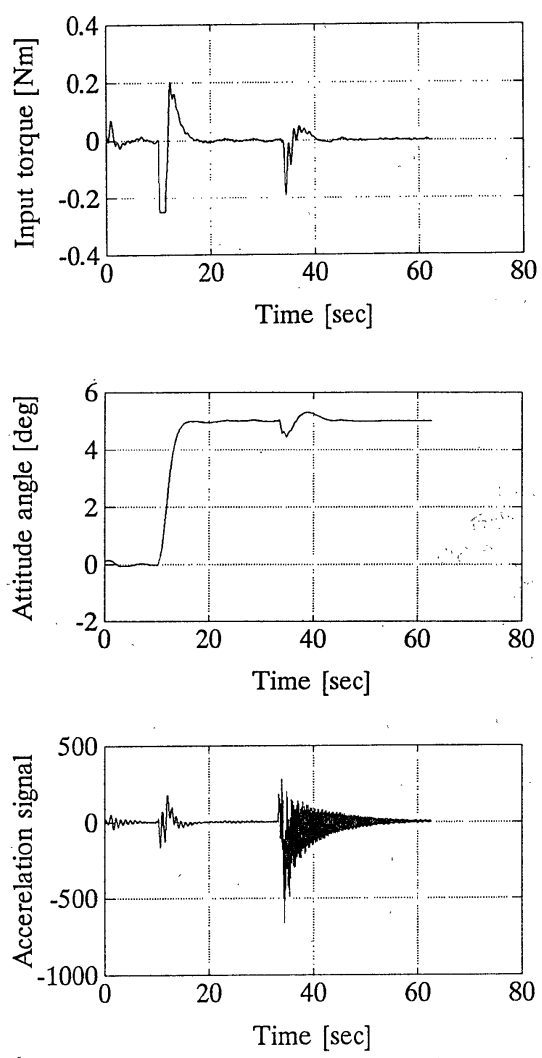

Fig. 11 Control experiment by using the state feedback control

ず, 最初の $10(\mathrm{~s})$ 間, 姿勢角 $(y)$ を $0(\mathrm{deg})$ にレギ ユレーションした後, 目標姿勢角を $5(\mathrm{deg})$ に変化さ せたときのステップ応答, さらに定常状態においてイ ンパルス的な外乱に対する制御性能を調べた. Fig.

11 に実験の一例を示した. ここで, 入力トルクには $\pm 0.25(\mathrm{Nm})$ のリミッタがかかっている. 図より, 目 標值追従性，外乱抑制性に優れた制御系が構成されて いるととがわかる. 特に, 加速度計の信号より, 振動 抑制性に優れているととが明らかになった. 現代制御 理論はパラメータのズレに脆弱な一面があるが，本制 御実験結果より, パラメータの同定は精度よく行われ ていることがわかる.

\section{5. おわりに}

本論文では将来の LSS の軌道上同定方式の候補と して，デシメーションを用いた同定法を取り上げ，実 験によりその有効性を明らかにした．との同定法は, 時間領域における最小 2 乗法にフィルタリングとい う周波数領域における信号処理を加えた方法であり， LSS のように特性が周波数領域において顕著に表わ 
れるシステムに対して特に有効である．また本論文 では, collocation の場合のみを取り扱ったが, noncollocation の場合にも本同定法は適用可能である (このとき, 付録に示したモードパラメータの計算法 は若干異なる). 今後, 衛星搭載計算機の制約, 入手 できるデータの制約などの宇宙空間における同定・制 御問題の特殊性を考慮した検討を行う.

\section{参 考 文 献}

1) S. N. Atluri and A.K. Amos: Large Space Structures: Dynamics and Control, Springer-Verlag (1988)

2）小松敬治：大規模柔軟構造物のモデリング，計測と制御， 28-4, 358/364 (1989)

3）飯野，足立，重政：フィルタリング操作を用いた連続時 間システムの同定，第 16 回制御理論シンポジウム資料, 193/196 (1987)

4）佐野 昭：ノンパラメトリックモデルの同定，計測と制 御, 28-4，316/322 (1989)

5) 足立，大明，重政：デシメーションを複数個用いたシス テム同定法 一ロボットアームの同定実験への適用一，計 測自動制御学会論文集， 26-9，1029/1035（1990）

6) 足立，重政，山口，木田：入出力データに基づいた柔軟 構造物の同定一 1 軸エアテーブル実験一，第 18 回制御理 論シンポジウム資料，209/212（1989）

7) 木田，藤原，池田：柔軟衛星制御の実験的検討，第 5 回 宇宙航空の誘導制御シンポジウム資料, 1/7 (1988)

8）重政 隆：計算機援用によるシステム同定，計測と制御， 28-4, 337/343 (1989)

9) 示村悦二郎：最適レギュレータ理論の実用化への展開, 電気学会論文誌 C，108-1，3/11 (1988)

10）足立，和泉沢，佐野：悪条件を考慮した伝達関数モデル の同定，電子情報通信学会論文誌，J70 A-3，410/418 (1987)

\section{《付録 モードパラメータの計算法》}

ここでは，ARMA モデルのパラメータ推定值から モードパラメータを計算する手順について，1 次振動

モードに焦点を絞って簡単にまとめる。

[Step 1] 慣性モーメント $(I)$ の計算：慣性モー メントは次式から計算できる.

$$
I=\left.\frac{\tilde{A}(z)}{\bar{B}(z)}\right|_{z=1}(\Delta T)^{2}
$$

ことで $\tilde{A}(z)$ は，同定された $\mathrm{AR}$ 部分の多項式 $A\left(z^{-1}\right)$ の反転多項式 $\bar{A}(z)$ の極のうち剛体モードに対応する 2 個の極を除いたものから構成される多項式であり， $\bar{B}(z)$ は同定された MA 部分の多項式 $B\left(z^{-1}\right)$ ，の反転 多項式である。

ただし，剛体モードに対応する極が求まっていなけ れば同定は失敗であり，同定条件（たとえば,デシメ
ーションの次数）を変更してもう一度同定を行う必要 がある。

（注意） 剛体モードは, $z$ 平面の単位円上の $z=1$ (2 重極) に対応するので,一般にパラメータ同定は 難しい.ただし，観測雑音が小さい場合には，以下に 示す出力信号の差分を用いるととによりこの問題点を 改善することが可能である ${ }^{103}$.

剛体モードが存在する，すなわち $z=1$ に二重極が 存在するという情報を用いると，次式が導かれる.

$$
\left.\bar{A}(z)\right|_{z=1}=0,\left.\frac{d}{d z} \bar{A}(z)\right|_{z=1}=0
$$

よって，同定モデルは次式のように変形できる。

$$
\begin{aligned}
{[1+} & \left.2 z^{-1}+3 z^{-2}+\cdots+(n-1) z^{-n-2}\right] \nabla^{2} y(k) \\
= & -\hat{a}_{1}\left[1+2 z^{-1}+\cdots+(n-2) z^{-n-3}\right] \nabla^{2} y(k-1) \\
& -\hat{a}_{2}\left[1+2 z^{-1}+\cdots+(n-3) z^{-n-4}\right] \nabla^{2} y(k-2) \\
& -\cdots-\hat{a}_{n-3}\left[1+2 z^{-1}\right] \nabla^{2} y(k-n+3) \\
& -\hat{a}_{n-2} \nabla^{2} y(k-n+2) \\
& +\hat{b}_{1} u(k-1)+\cdots+\hat{b}_{n} u(k-n)+\varepsilon(k)
\end{aligned}
$$

この同定モデルに最小 2 乗法を適用すればよい．乙こ で,

$$
\nabla^{2} y(k) \equiv[y(k)-y(k-1)]-[y(k-1)-y(k-2)]
$$

はyの二階差分を表わす。

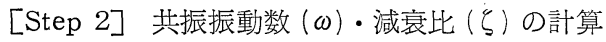
共振振動数 $\omega_{1}$, 減衰比 $\zeta_{1}$ は, 次式加ら計算できる.

$$
\begin{aligned}
& \omega_{1}=\sqrt{c_{1}^{2}+d_{1}^{2}} \\
& \zeta_{1}=-\frac{c_{1}}{\omega_{1}}
\end{aligned}
$$

ここで， $c_{1}, d_{1}$ は，同定された離散時間モデルの極 $z_{1}=\lambda_{1} \pm j \mu_{1}$ に対応する連続時間系の極 $s_{1}=c_{1} \pm j d_{1}$ である. よく知られているように，てれらの間にはつ ぎの関係式が成り立つ。

$$
\begin{aligned}
& c_{1}=\frac{1}{2 \Delta T} \ln \left(\lambda_{1}^{2}+\mu_{1}^{2}\right) \\
& d_{1}=-\frac{1}{\Delta T} \arctan \frac{\mu_{1}}{\lambda_{1}}
\end{aligned}
$$

[Step 3] 反共振点の固有振動数 $\left(\bar{\omega}_{1}\right)$ の計算 MA 部分に対応する多項式 $\bar{B}(z)$ の零点を計算す る.このとき，極に対応する複素共役対の 2 根から固 有振動数 $\left(\bar{\omega}_{1}\right)$ を Step 2 と同様の手順で計算する.

[Step 4] トルクアドミタンス $\left(\phi_{1}^{2}\right)$ の計算 $\phi_{1}^{2}$ は, 次式加ら計算できる。

$$
\phi_{1}^{2}=\frac{1}{I}\left[\left(\frac{\omega_{1}}{\bar{\omega}_{1}}\right)^{2}-1\right]
$$

